\title{
Peningkatan Pelayanan Terhadap Masyarakat Melalui Implementasi Smart Village Pada Desa Rimba Makmur
}

\author{
${\text { Nurjayadi*1, } \text { Torkis Nasution }^{2}, \text { Herwin }^{3} \text {, Khusaeri Andesa }}^{4}$ \\ 1,3,4Program Studi Manajemen Informatika, STMIK Amik Riau; Jl. Purwodadi Indah Km. 10 Panam, 0671- \\ 589561 \\ 2Program Studi Teknik Informatika, STMIK Amik Riau; Jl. Purwodadi Indah Km. 10 Panam, 0671-589561 \\ *e-mail: nurjayadi@stmik-amik-riau.ac.id
}

\begin{abstract}
Smart village presented as an answer to the increase in personnel services of the village the technology-based society. Community service aims to improve the quality of the infrastructures and information technology. Service target is a computer and information technology infrastructure at the village office, continued throughout the village head, social group, and informal sector. Problem solved in three stages, preparatory activities, implementation, and evaluation. Preparation was conducted through meetings with partners on plans to increase the quality of infrastructure technology. Implementation done by revamping the hardware and software technology accompanied by training, followed by discussion, and exercises in the form of simulation activities for all services provided by the Village Office. Evaluation activities are conducted for each stage by collecting and concluded the data from each phase of activity. After the evaluation, continued implementation of the implementation of the system directly interacts with the public. The result of the increase of information and computer technology have found success with indications of an increase in the satisfaction of internal and community.
\end{abstract}

Keywords: smart village, services, village office;

\begin{abstract}
Abstrak
Smart village dihadirkan sebagai jawaban untuk peningkatan layanan aparatur desa terhadap masyarakat berbasis teknologi. Pengabdian kepada masyarakat ini bertujuan untuk meningkatkan kualitas perangkat teknologi dan informasi. Sasaran pengabdian adalah infrastruktur teknologi informasi dan komputer pada kantor desa, dilanjutkan seluruh Kepala Dusun, RW, dan RT. Permasalahan diselesaikan dalam tiga tahapan kegiatan yaitu persiapan, pelaksanaan, dan evaluasi. Persiapan dilakukan dengan melaksanakan pertemuan dengan mitra mengenai rencana peningkatan kualitas teknologi infrastruktur. Pelaksanaan dilakukan dengan pembenahan teknologi perangkat keras dan lunak disertai dengan pelatihan, dilanjutkan dengan diskusi, dan latihan dalam bentuk kegiatan simulasi untuk seluruh pelayanan yang disediakan oleh Kantor Desa. Evaluasi kegiatan dilakukan untuk masing-masing tahap dengan mengumpulkan dan menyimpulkan data dari masing-masing tahapan kegiatan. Setelah evaluasi, dilanjutkan implementasi pelaksanaan sistem langsung berinteraksi dengan masyarakat. Hasil kegiatan peningkatan teknologi informasi dan komputer menunjukkan keberhasilan dengan indikasi adanya peningkatan kepuasaan dari internal maupun masyarakat.
\end{abstract}

Kata kunci: smart village, pelayanan, kantor desa;

\section{PENDAHULUAN}

Berdasarkan data BPS, pada saat ini (BPS, 2018) Negara Indonesia memiliki 66.048, 42048 desa telah mendapat akses Internet, sementara 24.000 desa di antaranya belum mendapatkan akses internet atau sinyalnya masih kurang bagus(Nurhasanah et al., 2015). Desa yang telah memiliki akses Internet (Holmes, Jones, \& Heap, 2015) dapat mengembangkan dan merencanakan layanan kepada masyarakat berbasis TIK. Sementara desa yang belum memiliki akses Internet dapat membangun solusi sendiri (Santoso et al., 2019) (Gangani, Dungrani, \& Jadeja, 2018) melalui sambungan antena point to point untuk di sebarkan ke masyarakat desa.

Dimensi smart village diadopsi dari dimensi kota cerdas yang disesuaikan dengan kondisi dan permasalahan yang terdapat di area desa (Luh, Srinadi, Nyoman, \& Puspita, 2018) 
(Herdiana, 2019). Dimensi yang menjadi penentu ketercapaian smart village adalah (Somwanshi et al., 2016) smart environtment, smart mobility, smart economy, smart living, smart governance, dan smart people. Setiap dimensi di ukur ketercapainnya melalui indikator yang telah ditetapkan, dengan demikian standar capaian smart village (Srivastava, 2018) dapat di ukur secara realible. Dalam pelaksanaan pengabdian ini dimensi yang di sasaran adalah smart village, melalui pelayanan publik dan sosial berupa peningkatan layanan terhadap masyarakat.

Desa Rimba Makmur terdiri atas 4 Kepala Dusun yang membawahi Rukun Warga dan Rukun Tetangga. Dalam pengelolaan administrasi desa Sekretaris Desa membawahi Kaur Pemerintahan, Kaur Umum, Kaur Keuangan, dan Kaur Pembangunan. Dalam menyelenggara-kan administrasi pada Dusun maupun di Kantor Desa seluruhnya dilaksanakan secara manual, sekalipun sudah tersedia komputer, namun masih difungsikan sebagai pengganti mesin ketik. Masyarakat berinteraksi secara langsung dengan pegawai kantor desa, dalam mengurus kelengkapan administrasi. Interaksi secara langsung, dengan suasana informal, turut mendukung iklim yang kondusif dalam menciptakan keharmonisan antara masyarakat staf desa. Posisi Kantor Desa berada di sisi Utara desa menyebabkan jarak tempuh dari sisi Selatan desa jarak tempuh lebih jauh. Kondisi saat ini akses layanan tidak selalu dapat berjalan dengan baik, hal ini disebabkan akses Internet sepenuhnya bergantung kepada penyelenggara operator telekmunikasi (Setyowardhani, Susanti, \& Riyanto, 2019). Ketersediaan sistem informasi layanan tidak berjalan optimal, diperlukan koneksi Internet dedicated point to point.

Masyarakat berinteraksi secara langsung dengan pegawai kantor desa (INFORMATIKA, 2016), dalam mengurus kelengkapan administrasi. Interaksi secara langsung, dengan suasana informal, turut mendukung iklim yang kondusif dalam menciptakan keharmonisan antara masyarakat staf desa. Media yang digunakan dalam perekaman data warga, baik layanan yang dibutuhkan, maupun kelengkapan surat keterangan masih dicatat dalam lembar buku agenda. Implementasi pemanfaatan teknologi dalam memberikan layanan kepada masyarakat masih belum ada.

Kantor desa telah menyediakan komputer desktop sebagai upaya implementasi teknologi, namun pegawai tidak selalu menggunakan dalam memberikan pelayanan. Justru lebih memilih menggunakan kertas sebagai media pembuatan surat menyurat. Berdasarkan wawancara dengan Pak Suwanto (Kaur Pemerintah, pegawai yang sedang bertugas), menyampaikan bahwa komputer yang tersedia turut membantu pekerjaannya, namun kendala yang dialami adalah: (1) Sistem Informasi e-Desa sudah tersedia, namun masih terkendala dalam ke-stabilan akses Internet (Santoso et al., 2019); (2) Komputer yang tersedia berupa desktop, sehingga tidak praktis, dalam ukuran, daya yang digunakan, dan waktu yang dibutuhkan untuk menggunakan; (3) Data masyarakat tersedia dalam Internet, bilamana akan membutuhkan data tersebut, harus datang ke kantor dan mengaktifkan komputer; (4) Sampai saat ini, daya listrik yang tersedia belum stabil sepenuhnya, hal ini dibuktikan komputer yang tersedia sering mengalami kerusakan karena faktor listrik; (5) Asupan daya relatif lebih besar, walaupun monitor telah diganti menjadi LCD, hal ini turut mempengaruhi kenaikan biaya beban pemakaian listrik.

Salah seorang pegawai dalam menyelesaikan pekerjaan memanfaatkan komputer sebagai media menyelenggarakan administrasi. Ibu Indri Astuti menjabat Kaur Keuangan Desa Rimba Makmur, menyampaikan bahwa dalam pengelolaan keuangan, komputer yang tersedia sudah membantu, namun masih ada kelemahan, manakala daya listrik tidak stabil, menempati ruang relatif besar, otomatisasi (Raharjo, 2019), penyimpanan tidak portable, dan gangguan kerusakan. Harapan yang disampaikan adalah: tersedianya peralatan dengan daya rendah, memudahkan portabilitas data, dan sistem aplikasi kependudukan dan otomatisasi keuangan. 


\section{METODE}

Metode pelaksanaan kegiatan implementasi smart village di Desa Rimba Makmur dengan diagram dibawah ini.

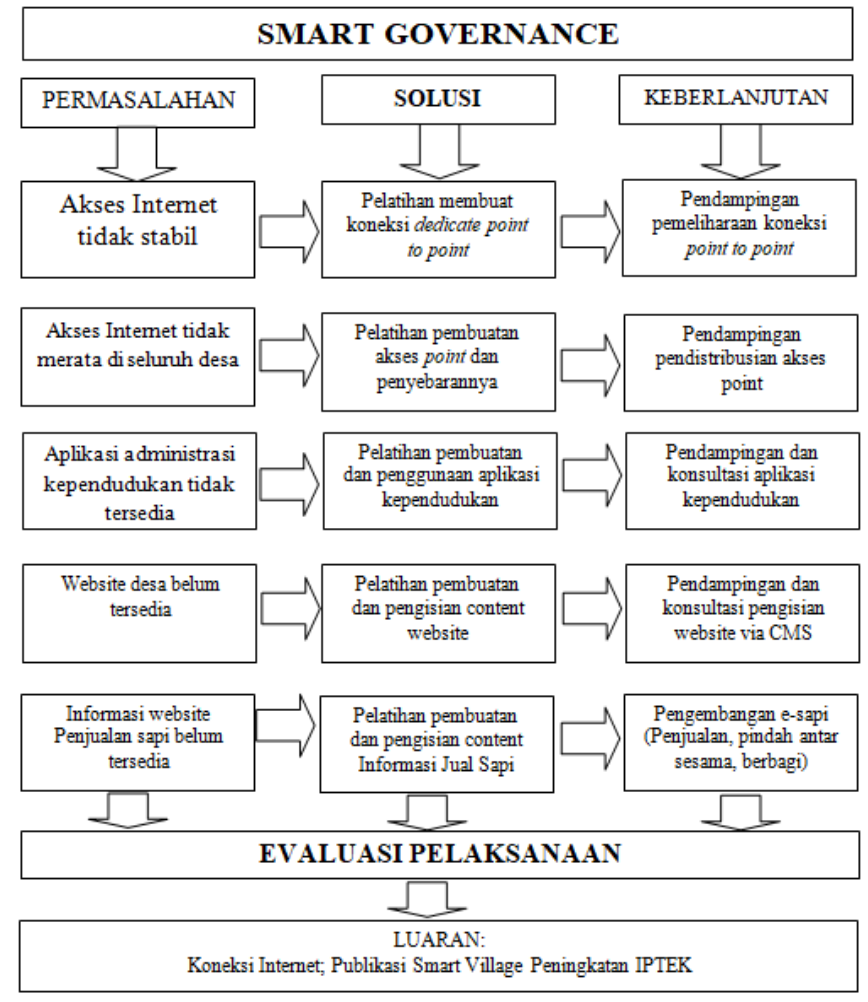

Gambar 1. Metode Pelaksanaan

Identifikasi permasalahan dilakukan melalui pertemuan langsung dengan aparatur desa dilanjutkan dengan observasi ke lapangan. Hasil identifikasi permasalahan yang telah diperoleh adalah: (1) ketersediaan akses internet yang tidak stabil di seluruh desa; (2) akses Internet tidak merata di seluruh desa; (3) belum tersedia aplikasi administrasi kependudukan; (4) belum tersedia portal desa; (5) sebagai desa lumbung sapi, namun tidak tersedia website yang memuat informasi penjualan sapi. Permasalahan yang telah di identifikasi, dimusyawarahkan dengan aparatur desa untuk mencari solusi. Solusi di berikan dalam kerangka implementasi smart village, yang mencakup pelatihan membuat koneksi dedicate point to point, pelathan pembuatan akses point dan penyebarannya, pelatihan pembuatan dan penggunaan aplikasi kependudukan, pelatihan pembuatan dan pengisian content website, dan pelatihan pembuatan dan pengisian content Informasi Jual Sapi. Keberlanjuan setelah pelatihan di lakukan pendapingan pemeliharaan koneksi point to point, pendampingan pendistribusian akses point, pendampingan dan konsultasi aplikasi kependudukan, pendapingan dan konsultasi pengisian website via CMS, dan pengembangan $e$-sapi.

\subsection{Pelaksanaan}

Pengabdian ini merupakan bagian dari pengabdian pengembangan desa mitra yang telah dilakukan para narasumber/dosen bersama tim di Desa Rimba Makmur, fokus pengabdian yang dilakukan adalah tentang peningkatan profesionalitas layanan aparatur elektronik bagi pegawai (Alkadafi, Rusdi, \& April, 2019). Tabel 1, menunjukkan kegiatan yang telah dilakukan oleh para narasumber bersama tim. 
Tabel 1. Kegiatan telah Dilakukan

\begin{tabular}{|c|c|c|c|}
\hline No. & $\begin{array}{l}\text { Waku } \\
\text { Kegiatan }\end{array}$ & Uraian kegiatan & Hasil \\
\hline 1. & $1 / 4 / 2019$ & $\begin{array}{l}\text { Upaya peningkatan layanan } \\
\text { oleh aparatur desa berbasis } \\
\text { Internet }\end{array}$ & $\begin{array}{l}\text { Disetujui rancangan pembuatan } \\
\text { halaman website }\end{array}$ \\
\hline 2. & $29 / 4 / 2019$ & $\begin{array}{l}\text { Launching Website Desa } \\
\text { www.rimbamakmur.desa.id dan } \\
\text { penggunaan bagi masyarakat }\end{array}$ & $\begin{array}{l}\text { Tersedia domain yang akan } \\
\text { digunakan }\end{array}$ \\
\hline 3. & $2 / 5 / 2019$ & $\begin{array}{l}\text { Pelatiahan Pembuatan Website } \\
\text { DesaBagi Aparatur Desa Rimba } \\
\text { Makmur }\end{array}$ & $\begin{array}{l}\text { Kemampuan dan pemahaman } \\
\text { dalam pembuatan halaman web } \\
\text { site serta penggunaan }\end{array}$ \\
\hline 4. & $2 / 5 / 2019$ & $\begin{array}{l}\text { Pelatiahan Pembuatan Aplikasi } \\
\text { Kependudukan } \\
\text { Bagi Admin Desa Rimba } \\
\text { Makmur }\end{array}$ & $\begin{array}{l}\text { Kemampuan mengoperasikan } \\
\text { halaman website kependudukan }\end{array}$ \\
\hline 5. & $2 / 5 / 2019$ & Pelatihan tenaga administrasi & $\begin{array}{l}\text { Kemampuan tenaga administrasi } \\
\text { dalam memberikan layanan } \\
\text { kepada masyarakat }\end{array}$ \\
\hline 6. & $1 / 6 / 2019$ & Pembuatan Domain & $\begin{array}{l}\text { Tersedia domain } \\
\text { http://www.rimbamakmur.desa.id }\end{array}$ \\
\hline 7. & $6 / 7 / 2019$ & $\begin{array}{l}\text { Pelatiahan Entry Data Website } \\
\text { Bagi Administrator Desa Rimba } \\
\text { Makmur }\end{array}$ & $\begin{array}{l}\text { Kemampuan administrator dalam } \\
\text { mengelola halaman website }\end{array}$ \\
\hline 8. & $6 / 7 / 2019$ & $\begin{array}{l}\text { Pelatiahan modul Data } \\
\text { Kependudukan } \\
\text { Bagi Aparatur Desa Rimba } \\
\text { Makmur }\end{array}$ & $\begin{array}{l}\text { Kemampuan aparatur desa dalam } \\
\text { melakukan pembaharuan } \\
\text { terhadap data kependudukan }\end{array}$ \\
\hline 9. & $6 / 7 / 2019$ & $\begin{array}{l}\text { Pelatihan Helpdesk bagi tenaga } \\
\text { teknis }\end{array}$ & $\begin{array}{l}\text { Kemampuan dalam melakukan } \\
\text { handling permasalahan dan sistem } \\
\text { penangangan }\end{array}$ \\
\hline 10. & $10 / 8 / 2019$ & $\begin{array}{l}\text { Pelatihan membuat koneksi } \\
\text { dedicate point to point }\end{array}$ & $\begin{array}{l}\text { Kemampuan dalam mengatasi } \\
\text { permasalahan sederhana dalam } \\
\text { koneksi Internet berbasis dedicate }\end{array}$ \\
\hline 11. & $10 / 8 / 2019$ & $\begin{array}{l}\text { Pelatihan pembuatan akses } \\
\text { point dan penyebarannya }\end{array}$ & $\begin{array}{l}\text { Kemampuan dalam menyebarkan } \\
\text { akses Intenet }\end{array}$ \\
\hline 12. & $10 / 8 / 2019$ & $\begin{array}{l}\text { Pelatihan pembuatan dan } \\
\text { penggunaan aplikasi } \\
\text { kependudukan }\end{array}$ & $\begin{array}{l}\text { Pengetahuan dalam pembuatan } \\
\text { program dan kemampuan dalam } \\
\text { mengoperaikan aplikasi } \\
\text { administrasi kependudukan }\end{array}$ \\
\hline
\end{tabular}

\subsection{Materi Pengabdian}

Pemanfaatan Teknolgi Informasi dan Komunikasi dalam menunjang kinerja di pemerintah tingkat desa harus didukung oleh ketersediaan Intener (Ardipandanto, Ardiyanti, Budiman, \& Sanur, 2015). Pembukaan jalur koneksi internet point to point yang disambungkan dari Ujung Batu Rokan, untuk menyediakan akses informasi di Kantor Desa Rimba Makmur. Akses Internet yang telah tersedia, selanjutnya di didistribusikan secara seimbang dalam kapasitas lebar kanal dan merata untuk seluruh ruangan, maupun area publik di lingkungan Kantor Desa. Perangkat yang digunakan untuk mendistribusikan jaringan internet, antara lain kabel Unshielded Twisted Pair (UTP), connector RG 45, Switch, access point, dan sumber catu daya. 
Akses jaringan Internet yang telah terpasang untuk seluruh gedung, ruangan, dan media display visual menggunakan sambungan langsung kabel. Masyarakat yang telah mendaftarkan perangkat ke dalam sistem akses Internet Desa, dapat menggunakan fasilitas akses melalui jaringan wireless. Setiap perangkat yang akses ke dalam jaringan telah di sesuaikan menggunakan Dynamic Configuration Protocol (DHCP) sehingga tidak diperlukan perubahan alamat Internet Protocol secara manual. Dengan pemanfaatan teknologi DHCP, pegawai kantor desa maupun masyarakat cukup mudah untuk mengakses layanan desa melalui fasilitas Internet yang telah tersedia (Somwanshi et al., 2016). Kantor desa sebagai pusat layanan dan hub untuk Intenet desa, telah menetapkan roadmap distribusi akases internet ke enam Dusun dilingkungan Desa Rimba Makmur. Disamping Dusun, juga akses dibuka untuk area publik (Singh \& Patel, 2018) antara lain: Mesjid, Pos Siskamling, area olah raga, kantor karang taruna, sekolah, dan sentra pasar.

Setelah tersedia akses Internet dan aplikasi e-desa, aparatur harus mengikuti proses pelatihan (Rachmawati, 2018) dan tetap meningkatkan kemampuan diri sebagai upaya mengantisipasi perubahan (Natarajan \& Ashok Kumar, 2017) oleh pemerintah dan tuntutan masyarakat. Seorang aparatur desa yang menyatakan diri profesional, hendaklah memiliki tiga hal pokok yang ada didalam dirinya, yang diantaranya (Anwari, 2018) meliputi:

a. Skill, yang artinya orang tersebut harus benar-benar ahli di bidangnya.

b. Knowledge, yang artinya orang tersebut harus dapat menguasai, minimalnya berwawasan mengenai ilmu lain yang berkaitan dengan bidangnya (Elfina, Wawo, \& Husin, 2019).

c. Attitude, yang artinya bukan hanya pintar, akan tapi harus memiliki etika yang diterapkan didalam bidangnya (Dewi \& Damayanthi, 2019).

\subsection{Struktur Smart Village}

Dalam memberikan pelayanan berbasis TIK, ada kerangka sebagai pegangan yang memudahkan aparatur untuk memberikan layanan administrasi desa kepada masyarakat. Kemampuan memberikan pelayanan sesuai dengan standar yang telah ditetapkan merupakan acuan utama dalam mengukur tingkat profesionalitas (Prahati, Zuhdi, \& Aguswan, 2017). Halaman website yang telah disediakan, terdiri atas:

1. Portal berita, memuat halaman statis yang dikelola melalui content management system. Dalam pengoperasian, di rancangan dan dibuat semudah-mudah untuk mempercepat dan menurunkan potensi kesalahan oleh operator (Prasetyo, 2019).

2. Administrasi kependudukan, menyediakan pengelolaan data yang melibatkan masyarakat secara langsung dan aparatur desa sesuai dengan tugas pokok dan fungsinya (Jain \& Sarkar, n.d.).

Hasil kegiatan yang diselenggarakan oleh Kantor Desa, disebarkan melalui pemuatan pada portal berita (Natarajan \& Ashok Kumar, 2017), yang terdiri atas:

1. Informasi, memuat berita terbaru berhubungan dengan kegiatan yang diselenggarakan maupun kejadian yang dialami oleh desa

2. Profil Desa, memuat sejarah desa, visi dan misi, kata Pengantar oleh Kepala Desa

3. Lembaga, memuat organsiasi yang berada dalam naungan desa, yang terdiri atas Karang Teruan, BPD, LPMD, RT/RW, BUMDES, Perpustakaan Desa, BAZ, PKK, Kelomok Tani (Razak et al., 2013), dan LINMAS

4. Layanan, memuat Penerbitan KK, Pembuatan KK, Pembuatan Akta, Pembuatan PKH, Jamkesda

5. Transparansi Desa, memuat transparansi anggaran, dan rencana kerja dan anggaran

6. Regulasi, memuat peraturan, edaran, dan panduan yang dikeluarkan oleh desa 


\section{HASIL DAN PEMBAHASAN}

Pada gambar 2(a), tim pengabdi melakukan pemasangan antena grid pada media tower yang menghadap ke ISP Telkom dengan sambungan Telkom Speedy. Setelah pemasangan antena selesai dan terhubung secara fisik, selanjutnya melakukan pemasangan kabel untuk mendistribusi-kan jaringan ke setiap ruangan melalui perangkat switch, terus tersambung menggunakan kabel untuk setiap komputer. Gambar 2(b), pengabdi menjelaskan kepada aparatur desa tentang cara kerja dan fungsi peralatan yang dipasang. Sementara untuk perangkat mobile dapat menggunakan fasilitas jaringan berbasis wireless. Walaupun kemudahan telah di tawarkan oleh jaringan berbasis wireless, namun kantor desa sampai saat ini masih tetap menggunakan sambungan kabel untuk setiap komputer dan media display TV. Gambar 3(a) tim pengabdi memasang dan merapikan kabel yang melewati area ruangan yang disaksiskan oleh Sekretaris Desa. Gambar 3(b), pengabdi memasang akses point di dinding, sehingga dapat dimanfaatkan oleh aparatur desa dan masyarakat.

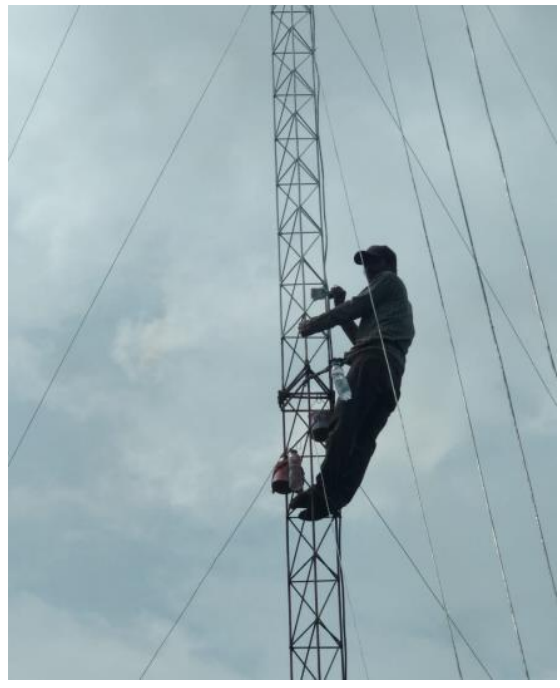

(a) Instalasi Antenna

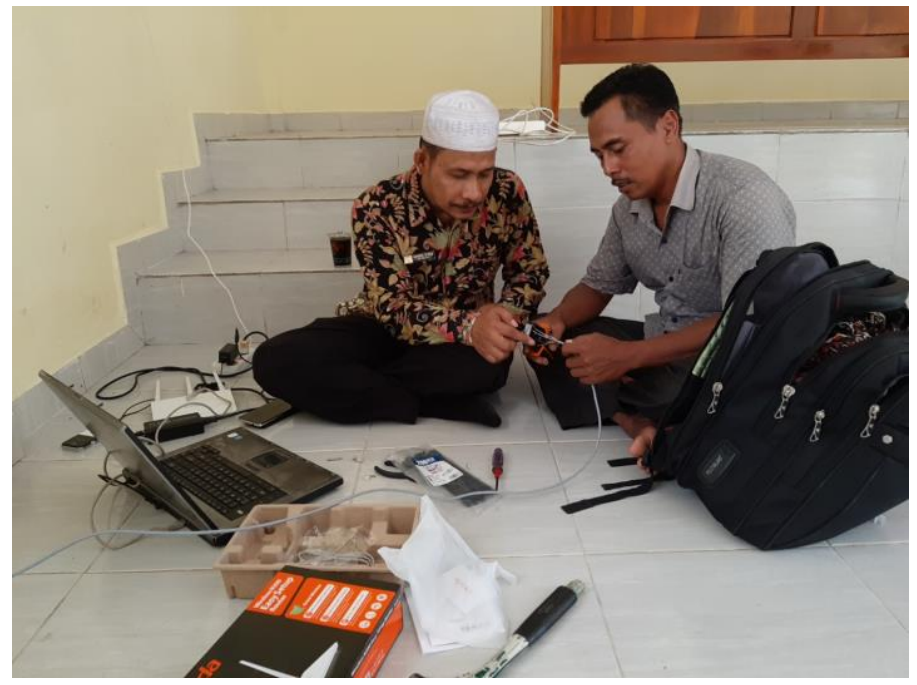

(b) Pemasangan Access Point

Gambar 2. Tenaga Lapangan Pengabdi sedang memasang

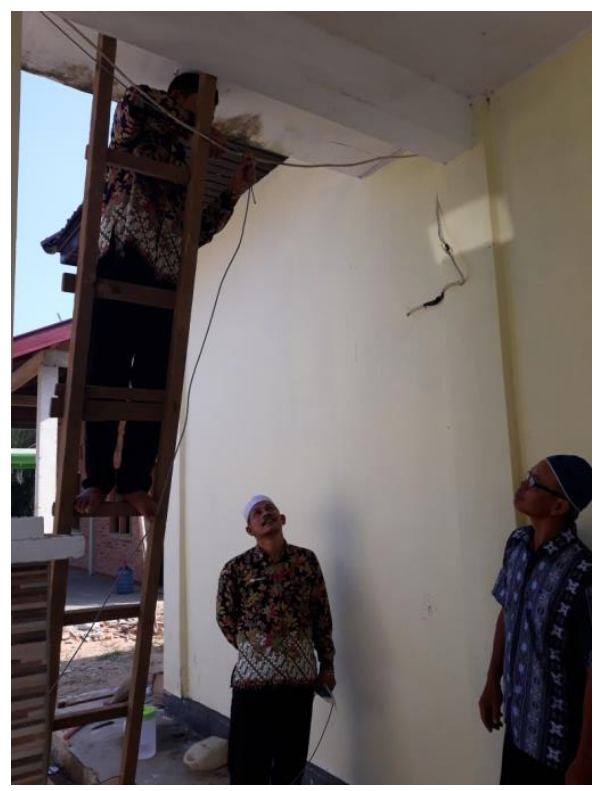

(a) Mahasiswa Memasang Instalasi

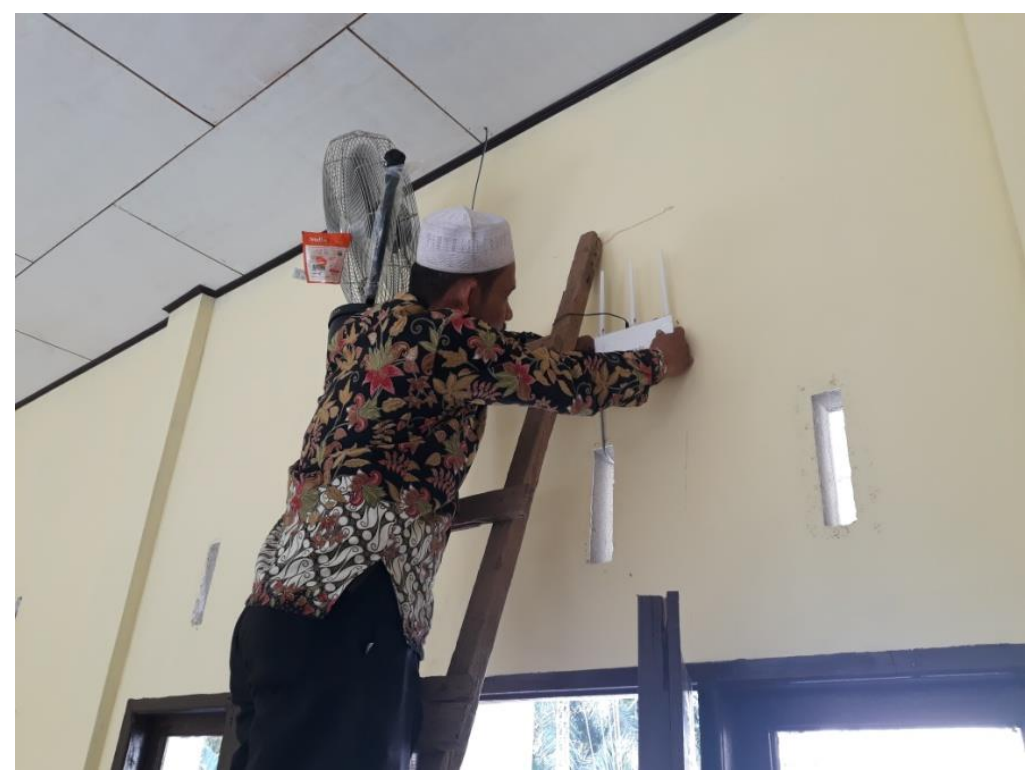

(b) Pengabdi Memeriksa Instalasi

Gambar 3. Pengabdi memasang akses point 
Gambar 4 tersebut merupakan, hasil dari pengabdian yang telah dilakukan. Desa Rimba Makmur telah memiliki website desa, dengan alamat www.rimbamakmur.desa.id.

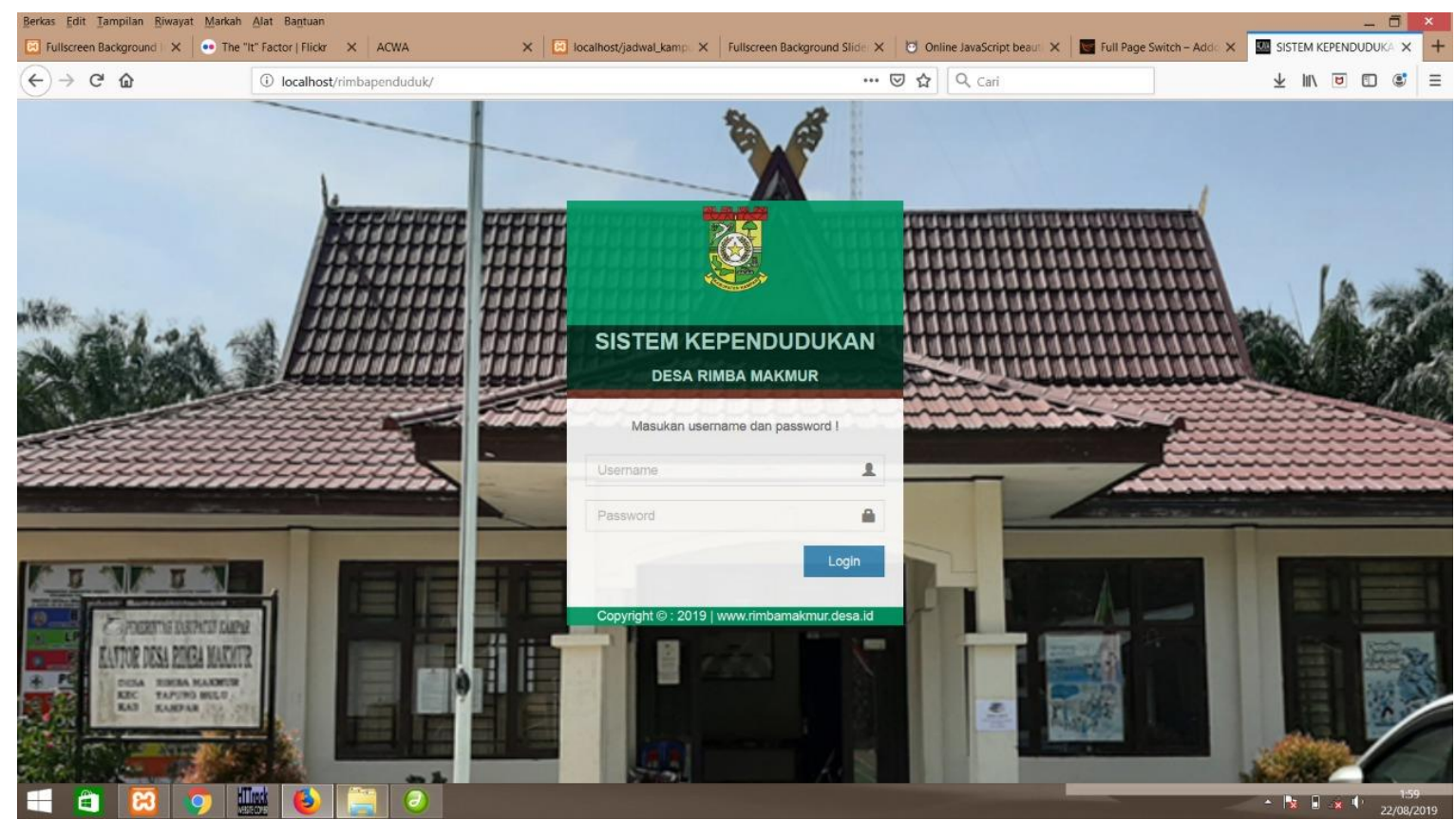

Gambar 4. Halaman login untuk masuk ke dalam sistem Administrasi Kependudukan

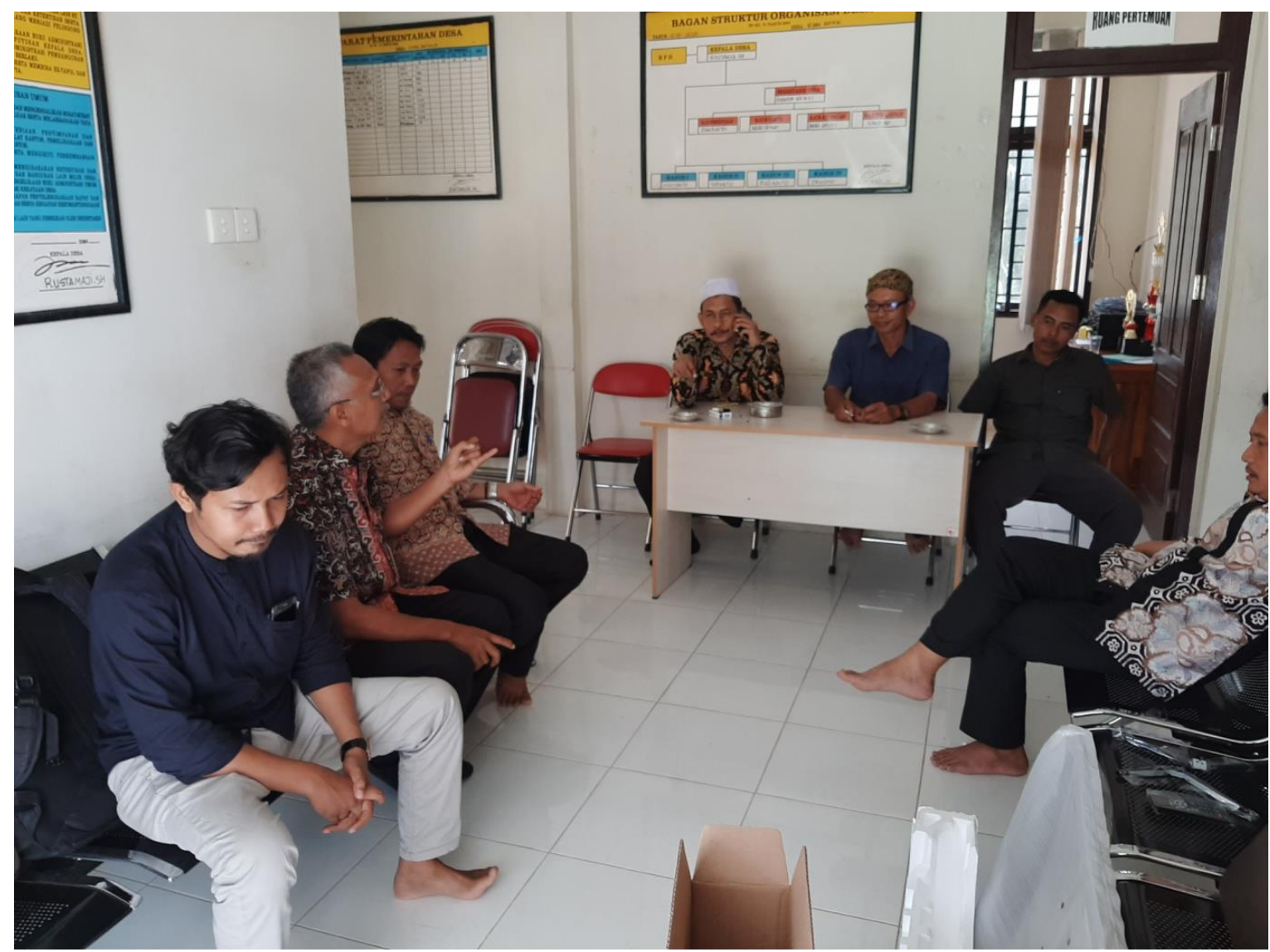

Gambar 5. Sosialisasi pentingnya membawa perangkat masing-masing 


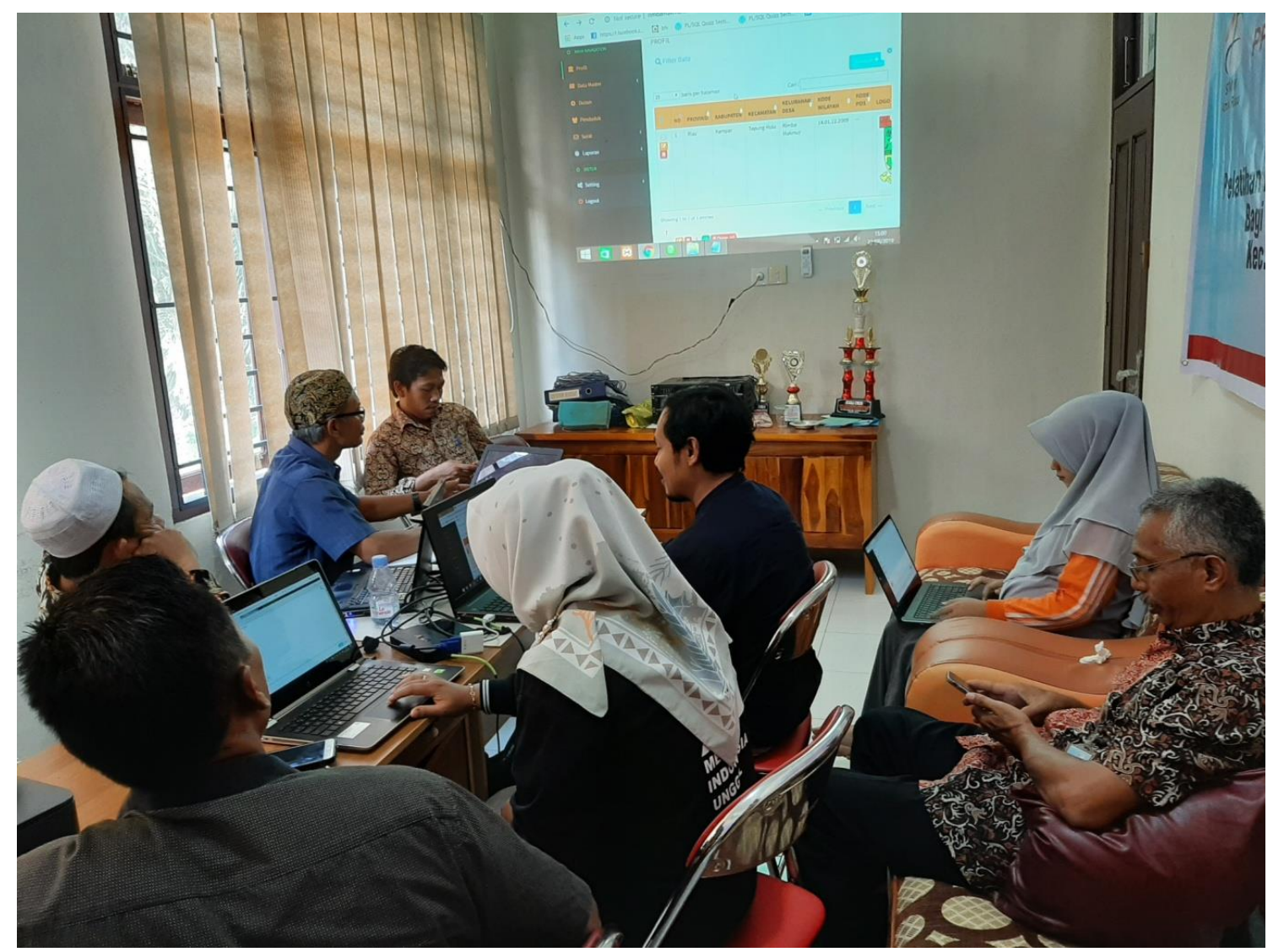

Gambar 6. Mengakses layanan e-desa menggunakan perangkat masing-masing

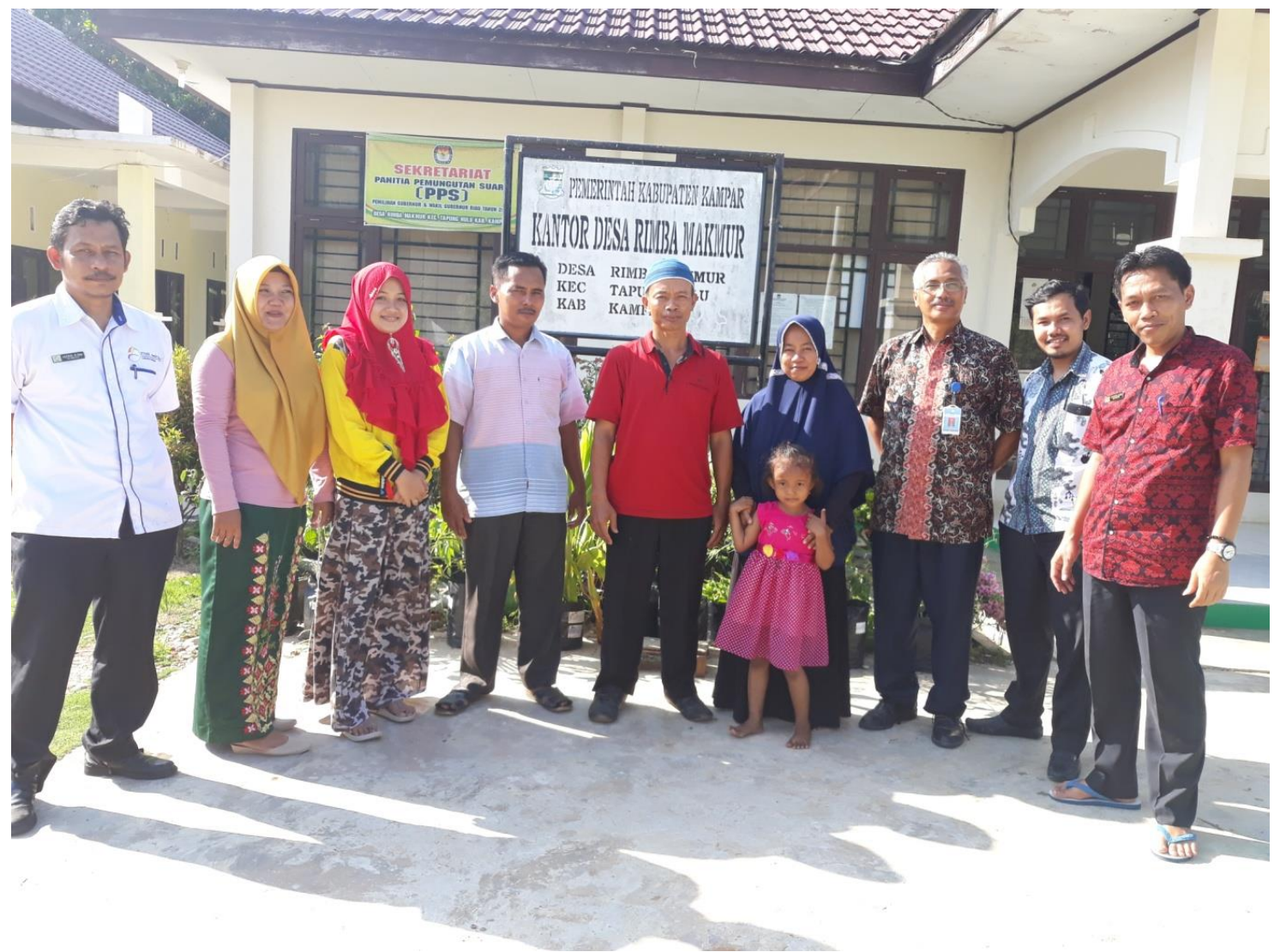

Gambar 7. Foto Bersama dengan Sekretaris Desa dan Aparatur 
Setelah membuka akses data internet melalui antena greed point to point, terjadi peningkatan terhadap akses halaman web site http://www.rimbamakmur.desa.id/, ditunjukkan pada tabel 1

Tabel 2. Frekwensi akses halaman website

\begin{tabular}{cccccccccc}
\hline Bulan & 1 & 2 & 3 & 4 & 5 & 6 & 7 & 8 & 9 \\
\hline Akses & 107 & 98 & 113 & 160 & 299 & 197 & 210 & 470 & 96 \\
\hline
\end{tabular}

Akses Internet sudah dapat dilakukan melalui media operator penyelenggara telekomunikasi, namun pembukaan akses Internet secara dedicated point to point baru dilakukan pada bulan Agustus 2019, perbandingan akses data pada bulan Juli 2019 sejumlah 210 akses, terjadi peningkatan di bulan Agustus 2019 menjadi 470 peningkatan $110 \%$.

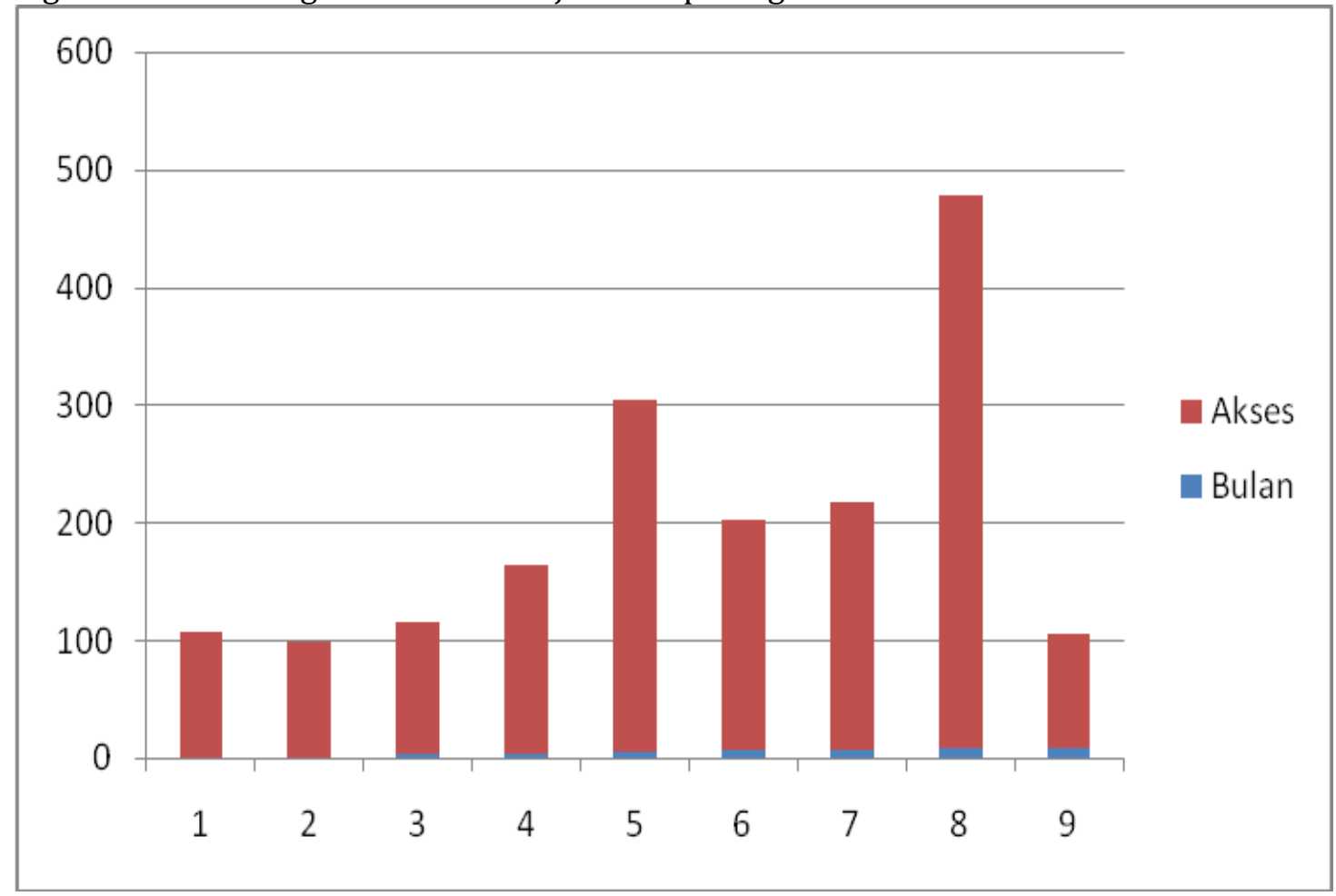

Gambar 8. Grafik Peningkatan Akses halaman website Desa Rimba Makmur

Setelah diadakannya pelatihan instalasi perangkat dan pemahaman perlunya menggunakan perangkat hemat energi, kemungkinan akan ditemukan kendalam dan perlu peningkatkan pemahaman serta kemampuan. Oleh karenanya, tim pengabdian membuat komunitas Grup Whatsap untuk mengantisipasi kendala (Setyowardhani et al., 2019) yang dialami peserta pasca pelatihan (Zavratnik, Kos, \& Duh, 2018). 


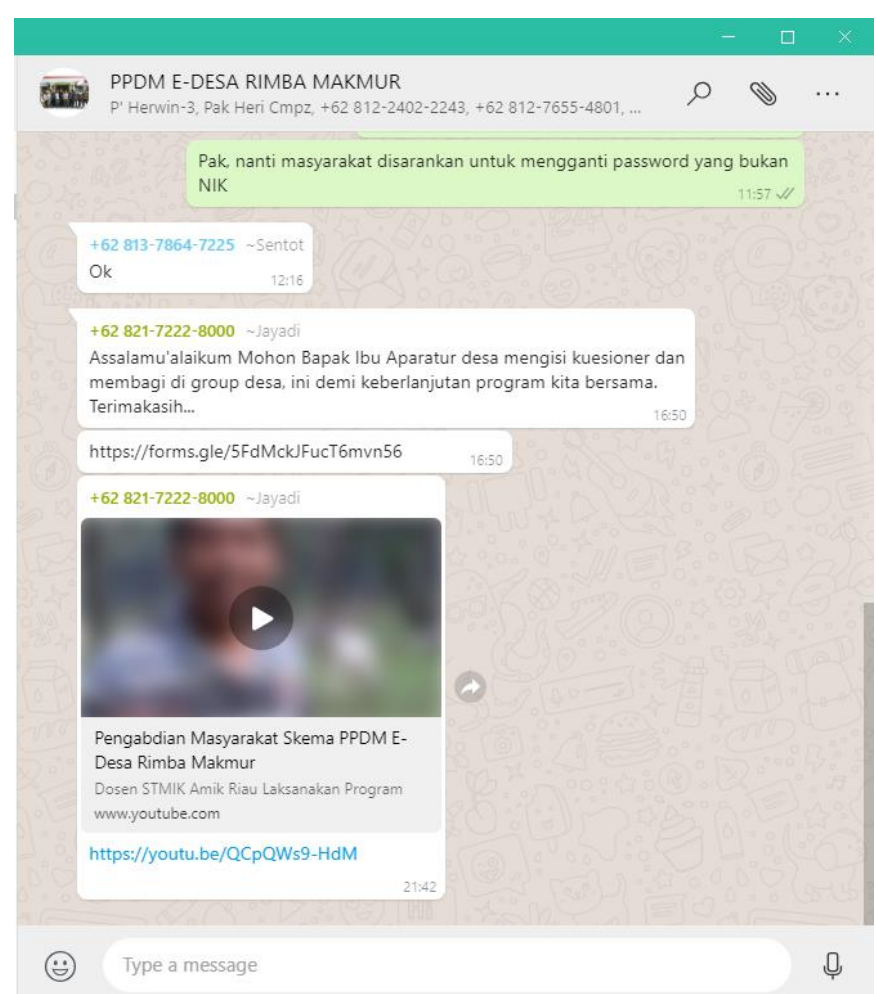

Gambar 9. Komunitas PPDM e-Desa Rimba Makmur

\section{KESIMPULAN}

Berdasarkan pelaksanaan pengabdian yang telah dilakukan, terdapat beberapa kesimpulan yang diperoleh yaitu:

a. Masyarakat Rimba Makmur telah 'bermigrasi' sebagai desa smart village dengan memanfaatkan internet sebagai langkah awal dalam memberikan informasi kepada masyarakat dengan memiliki website www.rimbamakmur.desa.id.

b. Aparatur Desa Rimba Makmur, telah memiliki kemampuan ketrampilan dalam mengoperasionalkan website untuk memberikan layanan kepada masyarakat.

Masyarakat Rimba Makmur, telah memiliki kemampuan dalam berinteraksi untuk kebutuhan administrasi kependudukan (Bogor, 2013) serta sumber berita melalui portal www.rimbamakmur.desa.id milik desa. Saran-saran untuk untuk penelitian lebih lanjut untuk menutup kekurangan penelitian. Tidak memuat saran-saran diluar untuk penelitian lanjut.

a. Pelaksanaan pengabdian dengan fokus pembuatan website di Desa Rimba Makmur, perlu dilanjutkan kepada desa-desa yang lain untuk mengembangkan potensi desa yang ada.

b. Pendampingan kepada desa harus terus dilakukan secara berkelajutan terutama pada pemberian layanan terhadap masyarakat berhubungan administrasi kependudukan, pemasukan berita, maupun pengembangan pada website desa.

\section{UCAPAN TERIMA KASIH}

Penulis mengucapkan terima kasih kepada Lembaga Penelitian dan Pengabdian Masyarakat STMIK Amik Riau dan Kemenristekdikti yang telah membantu dalam pelaksanaan program pengabdian masyarakat ini. Dan terimakasih kepada Pihak Desa Rima Makmur yang sudah membantu amal soleh pelaksanaan kegiatan ini. 


\section{DAFTAR PUSTAKA}

Alkadafi, M., Rusdi, \& April, M. (2019). Penataan Administrasi Pemerintahan Desa Di Desa Kualu Nenas Kecamatan Tambang Kabupaten Kampar. Dinamisia: Jurnal Pengabdian Kepada Masyarakat, 3(Juni 2019), 76-84.

Anwari. (2018). Pemahaman Pemanfaatan Teknologi Smart Village Di Tingkat Pemerintahan Desa. Seminar Nasional Hasil Pengabdian Kepada Masyarakat, 169-172.

Ardipandanto, A., Ardiyanti, H., Budiman, A., \& Sanur, D. (2015). Pengembangan Teknologi Informasi Komunikasi Bagi Pelayanan Publik Dan Keamanan Nasional Di Daerah (Pertama; I. Pahlevi, Ed.). Yogyakarta: Pusat Pengkajian, Pengolahan Data dan Informasi (P3DI) Sekretariat Jenderal DPR Republik Indonesia Gedung Nusantara I Lt. 2 Jl. Jenderal Gatot Subroto Jakarta Pusat 10270 Telp. (021) 5715409 Fax. (021) 5715245.

Bogor, P. K. (2013). Penerapan Teknologi Informasi dan Komunikasi untuk Mendukung Pengembangan e-Government Pemerintah Kota Bogor. Bogor.

BPS. (2018). Jumlah Desa/Kelurahan Menurut Provinsi dan Letak Geografi, 2003 - 2018. Retrieved from BPS website: https://www.bps.go.id/dynamictable/2015/09/18 00:00:00/906/jumlah-desa-kelurahan-menurut-provinsi-dan-letak-geografi-2003--2018.html

Dewi, L. A. M., \& Damayanthi, I. G. A. E. (2019). Pemoderasi Pengaruh Kompetensi Aparatur Desa Dan Sistem Pengendalian Internal Pada Pencegahan Fraud. E-Jurnal Akuntansi Universitas Udayana, 26(3),

2375-2395. https://doi.org/https://doi.org/10.24843/EJA.2019.v26.i03.p26

Elfina, Wawo, A. B., \& Husin. (2019). Pengaruh Kompetensi Aparatur Desa, Komitmen Pada Pengaruh Kompetensi Aparatur Desa, Komitmen Pada Tugas Dan Regulasi Terhadap Pengelolaan Tugas Dan Regulasi Terhadap Pengelolaan Keuangan Desa Di Kabupaten Bombana. Jurnal Progres Ekonomi Pembangunan (JPEP) Jurnal Progres Ekonomi Pembangunan (JPEP), 4(1). Retrieved from http://ojs.uho.ac.id/index.php/JPE

Gangani, A. D., Dungrani, M. A., \& Jadeja, K. Y. (2018). Planning Aspects for Betterment of Smart Indian Village. International Research Journal of Engineering and Technology (IRJET), 05 Issue:, 1709-1712. Retrieved from www.irjet.net

Herdiana, D. (2019). Pengembangan Konsep Smart Village bagi Desa-Desa di Indonesia Developing the Smart Village Concept for Indonesian Villages. 21(July), 0-16. https://doi.org/10.33164/iptekkom.21.1.2019.hal

Holmes, J., Jones, B., \& Heap, B. (2015). Smart Villages: New thinking for off-grid communities worldwide. In Science (Vol. 350). https://doi.org/10.1126/science.aad6521

INFORMATIKA, B. P. D. P. K. D. (2016). Prosiding seminar Posisi dan Tantangan Teknologi Informasi dan Komunikasi di Era Kelembagaan Desa Baru (C. S. D. Takariani \& D. Praditya, Eds.). Bandung: Penerbit: Balai Pengkajian dan Pengembangan Komunikasi dan Informatika Bandung Badan Penelitian dan Pengembangan Sumber Daya Manusia Kementerian Komunikasi dan Informatika RI Jl.

Jain, S. C., \& Sarkar, K. (n.d.). Assessing the 'Smart Village Potential ' of Villages in Mandi District. 105-117.

Luh, N., Srinadi, P., Nyoman, N., \& Puspita, H. (2018). Analisis Kebutuhan Fungsional Sistem Administrasi Sebagai Pendukung Implementasi Smart Village. 2018(Sentika), 23-24.

Natarajan, G., \& Ashok Kumar, L. (2017). Implementation of IoT based smart village for the rural development. International Journal of Mechanical Engineering and Technology, 8(8), 12121222.

Nurhasanah, Meidyasari, W. A., Musawir, A., A, S. G., Umriansyah, Purnama, K., ... Suryana, A. (2015). Roadmap Pengembangan Teknologi Informasi Komunikasi 2015-2020 Kementerian Pemuda dan Olahraga. Bagian Sistem Informasi Biro Humas dan Hukum Sekretariat Kementerian Pemuda dan Olahraga.

Prahati, Zuhdi, S., \& Aguswan. (2017). Penyuluhan Penyusunan Rencana Pembangunan Desa di Desa Kuapan Kecamatan Tambang Kabupaten Kampar. Dinamisia: Jurnal Pengabdian Kepada Masyarakat, 1(1), 94-99. 
Prasetyo, A. W. (2019). Telaah Pengembangan Kompetensi Aparatur Pemerintah Desa. Journal of Public Administration and Local Governance, 3(2), 105-115.

Rachmawati, R. (2018). Pengembangan Smart Village Untuk Penguatan Smart City dan Smart Regency. Jurnal Sistem Cerdas, 01(02), 12-18. https://doi.org/ISSN: 2622-8254

Raharjo, T. (2019). Pembuatan Rencana Anggaran Biaya bagi Badan Usaha Milik Desa di Kabupaten Tangerang. Dinamisia: Jurnal Pengabdian Kepada Masyarakat, 3(Juni), 53-58. https://doi.org/10.31849/dinamisia.v3i2.2858

Razak, N. A., Malik, J. A., Saeed, M., Holmes, J., Gevelt, T. Van, Holmes, J., ... Programme, V. (2013). a Development of Smart Village Implementation Plan for Agriculture: a Pioneer Project in Malaysia. Computing \& Informatics, 4Th International Conference, 2013, (024), 495-502.

Santoso, A. D., Fathin, C. A., Effendi, K. C., Novianto, A., Sumiar, H. R., Angendari, D. A. D., \& Putri, B. P. (2019). Desa Cerdas: Transformasi Kebijakan dan Pembangunan Desa Merespon Era Revolusi Industri 4.0 (Pertama; E. A. Purwanto \& D. Permadi, Eds.). Retrieved from h?p://cfds.fisipol.ugm.ac.i

Setyowardhani, H., Susanti, H., \& Riyanto. (2019). Optimalisasi Media Sosial sebagai Alat Promosi untuk Desa Wisata Lebakmuncang. Dinamisia : Jurnal Pengabdian Kepada Masyarakat, 3, 19-26. https://doi.org/10.31849/dinamisia.v3i2.2848

Singh, A., \& Patel, M. (2018). Achieving Inclusive Development Through Smart Village. PDPU Journal of Energy and Management, 3(1), 37-43.

Somwanshi, R., Shindepatil, U., Tule, D., Mankar, A., Ingle, N., Rajamanya, G., \& Deshmukh, A. (2016). Study and development of village as a smart village. International Journal of Scientific \& Engineering Research, 7(6), 395-408.

Srivastava, A. (2018). Smart Villages: Progress of Indian Era - Today's Need. International Journal for Research in Applied Science and Engineering Technology, 6(3), 783-788. https://doi.org/10.22214/ijraset.2018.3125

Zavratnik, V., Kos, A., \& Duh, E. S. (2018). Smart villages: Comprehensive review of initiatives and practices. Sustainability (Switzerland), 10(7). https://doi.org/10.3390/su10072559 